\title{
MYCHAJŁO KOCIUBYNSKI I WOLODYMYR WYNNYCZENKO: W POSZUKIWANIU WSPÓLNEGO MIANOWNIKA
}

\author{
RYSZARD KUPIDURA \\ Uniwersytet im. Adama Mickiewicza, Poznań — Polska \\ МИХАЙЛО КОЦЮБИНСЬКИЙ ТА ВОЛОДИМИР ВИННИЧЕНКО: \\ В ПОШУКАХ СПІЛЬНОГО ЗНАМЕННИКА
}

\author{
РИШАРД КУПІДУРА \\ Університет імені Адама Міцкевича, Познань - Польща
}

АНОТАЦІЯ. Автор здійснив спробу простежити, яким чином Михайло Коцюбинський та Володимир Винниченко за допомогою актуалізації чинників „влада” й „мова” реагували на колоніальну атмосферу Російської імперії на зламі століть. Їхні літературні тексти прочитані як форма діалогу з імперським центром, або ж як своєрідна відповідь на умови існування, які центр диктував своїй українській колонії.

\section{MYKHAILO KOTSIUBYNSKY AND VOLODYMYR VYNNYCHENKO: IN SEARCH OF A COMMON DENOMINATOR}

\author{
RYSZARD KUPIDURA \\ Adam Mickiewicz University, Poznan — Poland
}

\begin{abstract}
The author has made an attempt to trace the way Mykhailo Kotsiubynsky and Volodymyr Vynnychenko responded to the colonial atmosphere in the Russian Empire of the turn of the century, using the perspective of language and power. Their literary texts were therefore interpreted as a form of dialogue with the imperial center or the response to the conditions of functioning which the center dictated to its Ukrainian colony.
\end{abstract}

T ychajło Kociubynski i Wołodymyr Wynnyczenko. Podolak i człowiek 9912 kobieca" - pisał o Kociubynskim jego przyjaciel Czerniawski) oraz impulsywny, ambitny, ,bujny” charakter... Kociubynski był starszy od Wynnyczenki o całe szesnaście lat, jednak ich debiuty literackie dzieli jedynie siedem lat (odpowiednio 1895 i 1902). Sukcesy ukraińskiej prozy na początku XX wieku kojarzą się właśnie z imionami Mychajła Kociubynskiego i Wołodymyra Wynnyczenki" _ _ w ten sposób Wołodymyr Panczenko w 2003 roku uzasadniał wybór powyższych pisarzy na bohaterów swojej książki. Liczbę argumentów, zarówno tych literackich, jak i tych biograficznych, na rzecz zasadności zestawienia twórczości wybitnych ukraińskich nowelistów, można znacząco zwiększyć, tym bardziej, jeśli przyjmie się, że warto porównywać teksty autorów, których poza wspólnym okresem przebywania na scenie literackiej dzieli niemalże wszystko.

${ }^{1}$ В. Панченко, Introduzione, [в:] Капрійські сюжети: „, Італійська” проза Михайла Коињюбинського та Володимира Винниченка, упор. В. Панчен ко, Київ 2003, s. 6. 
W niniejszym artykule autor — przy użyciu perspektywy języka i władzy — postawił sobie za zadanie prześledzenie, w jaki sposób wspomniani pisarze reagowali na kolonialną atmosferę Imperium Rosyjskiego przełomu wieków. Ich teksty literackie (w przypadku Wynnyczenki materiał badawczy został zawężony do tzw. „małej prozy") zostały zatem odczytane jako forma dialogowania z imperialnym centrum czy też odpowiedź na warunki funkcjonowania, które centrum to podyktowało swej ukraińskiej kolonii.

Język. Strategia Mychajła Kociubynskiego w stosunku do języka rosyjskiego, czyli języka, którym jako urzędnik państwowy zobowiązany był posługiwać się na co dzień, uwidacznia się poprzez zestawienie z innymi językami, których ślady odnaleźć można w tekstach pisarza. Autor Intermezzo lubował się w bowiem we wplataniu obcojęzycznych słów, wypowiedzi, czasami nawet fragmentów utworów literackich. Przez całą twórczość czernihowskiego pisarza przewija się zatem mozaika narodów, ich języków i obyczajów. Czytelnik podczas lektury natrafia na język rumuński, krymskotatarski, jidysz, polski, turecki, romski, niemiecki czy włoski. Kociubynski stosował $\mathrm{w}$ dialogach swoich bohaterów również wtrącenia $\mathrm{z}$ języka francuskiego lub z łaciny. Wspomniana mozaika nie jest jednak kompletna. Z twórczości pisarza całkowicie bowiem został wyparty język rosyjski. I to pomimo tego, że rosyjskie postaci obecne są na kartach opowiadań Kociubynskiego. Obrazy Rosjan-Moskali, obecne choćby w Debiucie [Дебют], Pojedynku [Поєдинок], czy noweli Sen [Сон], sa jednak skrajnie zmarginalizowane i niejako pozbawione mowy. Kociubynski nie tylko nie udziela im głosu — wszystkie te postaci pojawiają się nagle, jakby nie proszone i szybko opuszczają scenę utworu.

Autor Persona grata obsesyjnie dba o czystość swojej ukraińszczyzny. ${ }^{2}$ Dokonuje wielokrotnych poprawek, obawia się, by w tekście końcowym nie pojawiły się niepożądane rusycyzmy. Największym bodaj wyzwaniem stanowi dla niego kreacja postaci Karpo Petrowycza Zajczyka z opowiadania Prezent na urodziny [Подapyнок на іменини]. Postać carskiego urzędnika i karierowicza niemalże domagała się użycia zapożyczeń z języka rosyjskiego. Kociubynski wytrzymuje jednak i tę próbę, a stworzone przez niego dialogi Karpo Petrowycza i Susanny wniosły sporo nowych słów do słownika ukraińskich kolokwializmów. Swą zasadę pisarz złamie tylko raz w noweli Nie wińcie koni [Коні не винні]. W jednej z ostatnich scen tekstu Antoszasyn bogatego ziemianina Arkadija Petrowycza — w obawie przed rozparcelowaniem wśród chłopów rodowego majątku wykrzykuje znamienne Eto niel'zja! Nie ma to jednak wiele wspólnego ze wspomnianą wyżej wielobarwną kompozycją narodów i ich języków.

Pisarz, któremu proponowano wyższe honoraria za tworzenie w języku rosyjskim, przez całą swą karierę pozostał wierny ideałom Bractwa Tarasowców, do którego należał w latach młodości. Postulat tajnego ugrupowania, by język ukraiński zapanował na całej Ukrainie: w rodzinie, w sprawach zarówno prywatnych, jak i społecznych, w literaturze i nawet w stosunkach $\mathrm{z}$ innymi narodami, które mieszkają na ziemiach ukraińskich całkowicie zdeterminował twórczość Mychajła Kociubynskiego. ${ }^{3}$

Tymczasem dla Wołodymyra Wynnyczenki popularyzacja języka ukraińskiego jest w takim samym stopniu ważna, jak propagowanie idei socjalistycznych.

${ }^{2}$ Przy okazji warto zaznaczyć, że najpopularniejsze wydanie dzieł Kociubynskiego z lat 70. (M. Koцюбинський, Твори у 7 m., Київ 1973-1975) zawiera teksty zredagowane według obowiązujących ówcześnie zasad pisowni. Zachowane w Instytucie Literatury NANU rękopisy świadczą o znaczącym wpływie dialektu podolskiego na język pisarza.

${ }^{3}$ Por.: С. Наумо в, Братство тарасівц̧ів, [в:] „Український історичний журнал”, 1999, № 5. 
Wyrabianie świadomości klasowej w jego wczesnych utworach zawsze idzie w parze z powrotem do korzystania z języka ojczystego. Tak jest w przypadku opowiadania Pracy! [Роботи!], w którym emancypantka Ludmiła sprawuje pieczę nad rozwojem robotnika Maksyma. Nowicjusz ruchu socjalistycznego dzięki kobiecie odbudowuje w sobie szacunek do języka ojczystego: „Я потім через вас і вивчив нашу мову... Спершу я сміявся навіть, що по-українськи, по-хохлацьки... А потім, як ви стали говорити з нами й вияснили все... А особливо, що ви такі серйозні й такі.... інтелігентка... говорите по-нашому, по-мужицькому"4.

Również Mykoła Hanenko z Zaręczyn [Заручини], który pragnie w narodnickim duchu wychować Halę - swą przyszłą żonę, przyjaciela i powiernika, rozpoczyna proces oświecania dziewczyny od nauki języka ukraińskiego.

Strategia literacka Wołodymyra Wynnyczenki odnośnie wszechobecnego języka rosyjskiego jest jednak odwrotna niż w przypadku Mychajła Kociubynskiego. Autor Ziny [3іна] pragnie odzwierciedlić w tekście literackim sytuacjęjęzykową na ziemiach ukraińskich przełomu wieków. W tym celu do swych utworów wprowadza nie tylko liczne rusycyzmy, ale i całe frazy wypowiedziane w surżyku. U Wynnyczenki w ten sposób wypowiadają się zazwyczaj negatywni bohaterowie - strażnicy więzienni, żandarmi, kozacy rozpędzający manifestacje robotników, prowincjonalne naczalstwo itd. W noweli Oczekiwanie [Чекання] spotykamy scenę, gdy ukraiński chłop $\mathrm{w}$ rozmowie $\mathrm{z}$ przedstawicielami władzy przechodzi na język rosyjski, co oddaje atmosferę skolonizowania. Pisarz wartościuje obydwa języki. Mówienie po ukraińsku jest dla niego oznaką oświecenia i duchowego rozwoju człowieka. Niezgrabny rosyjski oznacza, że jego nosiciel jest jedynie mieszkańcem imperialnej prowincji, pozostającym w sferze oddziaływania centrum. Najbardziej udanie zabieg ten wyszedł Wynnyczence we wspomnianych Zaręczynach. Hala, która deklaruje chęć przemiany i życia według progresywnych ideałów, uczy się języka ukraińskiego. Stopniowa demaskacja tej osoby, ujawnianie się jej prawdziwych intencji oraz wyrachowanego charakteru układają się paralelnie z degradacją jej mowy. Hala mówi coraz gorzej, jej ukraińszczyzna coraz bardziej zabrudzona jest przez rusycyzmy:

- Любіш? Да? Говорі же, проклятий, глупий. Говорі, любіш?

- Не «говорі», а говори!.

- Ах, оставь, пожалуста, хоть теперь. Говори. Ну, скорей!'.

Wołodymyr Wynnyczenko osiągnął w ten sposób efekt defetyszyzacji języka rosyjskiego jako mowy Imperium. Dla jego bohaterów nie stanowi on obiektu pożądania. W zwulgaryzowanej formie tego języka wypowiadają się jednostki zacofane, stawiające opór progresywnym ideom socjalizmu. Język postępu to u Wynnyczenki język ukraiński.

Warto zauważyć, że przesłanie autora Pracy! nie znalazło uznania wśród współczesnych. Iwan Neczuj-Łewycki oraz Mykoła Worony krytykowali Wynnyczenkę za używanie licznych rusycyzmów. Co ciekawe, pewien ich walor dostrzegł zachodnioukraiński krytyk Mychajło Rudnycki. Jego zdaniem „moskalizmy” u Wynnyczenki, choć i wpływały na poziom artystyczny utworu, to jednak determinowały powstawanie neologizmów, które z czasem zasiliły ukraiński język literacki. ${ }^{6}$

Wydaje się, że Rudnycki w swej ocenie poszedł w dobrą stronę. Jako jedyny zauważył, że wynnyczenkowski językowy galimatias wcale nie musiał szkodzić

${ }^{4}$ В. Винниченко, Краса і сила, Київ 1989, с. 150.

${ }^{5}$ Там само, с. 196.

${ }^{6}$ Див.: Т. Маслянчч к, Проза В.Винниченка: проблеми текстології, Автореф. дис. канд. філол. наук, [в:] Електронний ресурс: http://disser.com.ua/contents/5414.html (12.08.2013). 
ukraińszczyźnie, o czystość której tak bardzo obawiali się rodzimi puryści. Paradoksalnym rezultatem wykluczających praktyk Imperium w stosunku do języka ukraińskiego była bowiem jego elastyczność, chłonność i zdolność do przyswajania zewnętrznego materiału. To, co nie szkodziło nie do końca uformowanej jeszcze ukraińszczyźnie, było zabójcze dla posiadającego stabilny kręgosłup gramatyczny i leksykalny języka rosyjskiego. Spotwarzony obraz „wielkiej i potężnej” ruszczyzny, jakby zainfekowanej wirusem, był sygnałem dla obu stron spotkania kolonialnego, że pełna asymilacja nie jest możliwa, że „skutki uboczne” przeważają na realnymi korzyściami i wkrótce mogą obrócić się przeciwko kolonizatorom.

Sytuacja językowa na ziemiach ukraińskich, wchodzących do składu Imperium Rosyjskiego odcisnęła swoje piętno na twórczości zarówno Mychajła Kociubynskiego, jak i Wołodymyra Wynnyczenki. Każdy z nich jednak reagował na nią w inny charakterystyczny dla swojej maniery pisarskiej — sposób. Dla autora Intermezzo literatura jest świątynią, do której nie należy zanosić brudu codzienności w postaci rusycyzmów czy wulgaryzmów. Wszechobecny język rosyjski stanowi dlań uciążliwe jarzmo, które pisarz zrzuca z siebie, wkraczając do przestrzeni literatury. Uzyskując w niej schronienie, pieczołowicie tka swoje teksty, dbając przy tym, aby każda z nicisłów znalazła swą odpowiednią formę i miejsce. Wynnyczenko mierzy się natomiast z problemem rusyfikacji za pomocą przewrotnego chwytu wprowadzenia do tekstu literackiego zdegenerowanej formy języka rosyjskiego, przez co pozbawia go aury imperialnej atrakcyjności. Efekt ten uzyskuje metodą, którą swego czasu Iwan Franko zręcznie określił jako ,łapanie życia na gorącym uczynku”.

Niemalże manufakturowe podejście do pisania Wynnyczenki oraz wypielęgnowany styl Kociubynskiego powodowały, że pisarze wypowiadali się wzajemnie o sobie z dozą pewnej ironii. Kogo się u nas czyta? Wynnyczenkę. O kim wszędzie prowadzi się rozmowy, jeśli tylko zejdzie ona na tematy literackie? O Wynnyczence. Kogo kupuja? Znowu Wynnyczenke, — pisał w 1909 roku Kociubynski ${ }^{7}$. Kociubynski wysiaduje swoje nowele niczym kwoka kurczęta — rewanżował się Wynnyczenko ${ }^{8}$.

Władza. Jeżeli Mychajło Kociubynski i Wołodymyr Wynnyczenko dość znacząco rozchodzili się w ocenie najbardziej istotnych problemów ich ówczesnego świata, takich jak granice postępu (Dla dobra ogólu [Для загального добра] vs Panienka [Баришенька]), opozycja miasta i wsi (Intermezzo vs Na łonie przyrody [На лоні природи]), czy w końcu emancypacja kobiet (Sen vs Zina), to w przypadku literackiej recepcji problematyki władzy obaj pisarze zachowali niemalże pełną zgodność.

Przez wieki naród ukraiński żył pod obcymi rządami. W tym czasie wykrystalizowało się przekonanie, że władzę zawsze sprawuje obcy (Polak, Rosjanin, Niemiec), który nie tylko nie dba o swych ukraińskich poddanych i nie tylko wykorzystuje ich jako siłę roboczą, ale przede wszystkim ruguje miejscową tożsamość. Przystawanie do najeźdźcy z jednej strony było kuszące, bo wabiło obietnicą awansu społecznego, z drugiej zaś, jako zdrada narodowa, odbijało się negatywnie na kondycji moralnej jednostki.

Ukraińska bezpaństwowość bezsprzecznie zdeterminowała charakter rozwoju rodzimej literatury. Z braku elit politycznych, pisarze ukraińscy obarczeni byli nie tylko obowiązkami wobec sztuki, ale także wymagało się od nich odpowiedniej

7 Див.: О. Івахно, Володар дум свого покоління, [в:] Електронний ресурс: ukrgazeta.plus. org.ua/article.php?ida=1692 (12.10.2013).

${ }^{8}$ О. Балабко, Скарб родини Коиюбинських, [в:] Електронний peсурс: www.ukrlit.vn.ua/ article1/1860.html (12.10.2013). 
postawy obywatelskiej. To z kolei wpływało na podejmowana w utworach tematyke oraz walnie przyczyniło się do powstania odrębnego nurtu literackiego, który w drugiej połowie XIX wieku wykrystalizował się jako realizm narodnicki.

Na początku XX wieku Mychajło Kociubynski oraz Wołodymyr Wynnyczenko znaleźli się wśród najważniejszych reformatorów literatury ukraińskiej. Jednak w obydwu przypadkach odejście od narodnickiej stylistyki nie przełożyło się na zmianę w tradycyjnym postrzeganiu relacji władza-jednostka jako opozycji, w której składowe są poddawane wartościowaniu i stanowią antagonistyczną, wrogą sobie parę.

Charakterystyczne, że ani Wynnyczenko, ani Kociubynski w swych nowelach i opowiadaniach nie odwoływali się do ukraińskiej przeszłości. Wyjątkiem jest jedynie opowiadanie Za wysokq сепе̨[Дорогою иіною] z 1901 roku Kociubynskiego, napisane po wpływem panującej ówcześnie mody literackiej. W tekście, przedstawiającym historię ucieczki pary ukraińskich chłopów do Turcji, opozycja władzy i jednostki została zaznaczona już na samym wstępie: „Діялось се в тридцятих роках минулого століття. Українське поспільство, поборене у класовій боротьбі, з ярмом панщизняної неволі на шиї, тягло свою долю з глухим ремством. То не віл був у ярмі, звичайний господарський віл, якого паша й спочинок могли зробити щасливим: ярмо було накладене на шию дикому турові, загнаному, знесиленому, але овіяному ще степовим вітром, із не втраченим іще смаком волі, широких просторів. Він йшов у ярмі, скорившись силі, хоч часом із гніву очі йому наливались кров'ю, і тоді він хвицав ногами і наставляв роги... Вільний дух народу ще тлів під попелом неволі. Свіжі традиції волі, такі свіжі, що часом трудно було відрізнити сьогодні од вчора, підтримували жевріючу під попелом іскру. Старше покоління, свідок іншого життя, показувало ще на долонях мозолі від шаблі, піднятої в оборону народних і людських прав. Пісня волі, споетизованої, може, в дні лихоліття, чаруючим акордом лунала в серцях молоді, поривала ії туди, де ще не чуть кайданів, скованих на людей людьми. На широкі бессарабські степи, вільні, без пана й панщини, рвалась гаряча уява й тягла за собою сотки й тисячі..."”.

Kociubynski sięga do przeszłości ukraińskiej nie po to, by ukazać dawne tradycje państwotwórcze, ale w celu wzbudzenia w czytelniku nostalgię za czasami, kiedy Ukraińcy stawiali aktywny opór cudzej władzy.

Wynnyczenko, choć w „małej prozie” nie odwoływał się do tematów historycznych, to w wypowiedziach jego bohaterów zauważalne jest podobne odniesienie do przeszłości, jak w utworach Kociubynskiego. Młody rewolucjonista, główny bohater opowiadania Choma Priadka [Хома Прядка] tak wyobraża sobie dni ukraińskiej świetności: „В той час в душі моїй жили козаки, Січ Запорозька, гайдамаки, вперте, велетенське прагнення волі та боротьба за неї. Україна мені здавалася безкрайною, невичерпаним джерелом великих можливостів, і через те, що вона була безкрая, я й хотів власними ногами обійти ऑї, власними очима побачити всі тайни ї’”’

Dni ukraińskiej świetności asocjują się zatem obydwu pisarzom ze stanem buntu, aktywnym przeciwstawieniem się uciskowi i niesprawiedliwości dziejowej.

Takie postrzeganie przeszłości przełożyło się zarówno w jednym, jak i w drugim przypadku na rozumienie rzeczywistości, w której żyli pisarze. Ich dorobek twórczy daje temu konkretne świadectwa.

\footnotetext{
${ }^{9}$ М. Коцюбинський, Твори..., т. 2, с. 90.

${ }^{10}$ В. Винниченко, Kpaca..., с. 707.
} 
W 1912 roku Kociubynski opublikował zawierające wątki autobiograficzne opowiadanie Prezent na urodziny. Tekst ten można rozpatrywać jako stanowisko Kociubynskiego odnośnie kariery, czyli stopniowej akumulacji władzy, w rzeczywistości Imperium Rosyjskiego.

Karpo Petrowycz Zajczyk - posiadający prawdopodobnie swój prototyp w osobie ojca Kociubynskiego - pełni od niedawna funkcję policyjnego nadzorcy. Swój awans zawdzięcza temu, że jego małżonka, była prostytutka Susanna wykupuje go, spędzając noc z przełożonym męża. Rozwój kariery zostaje zatem okupiony degradacją moralną. Patologiczna sytuacja zaczyna również dotyczyć dziecka, którego ojciec chce nauczyć odporności na widok ludzkiego cierpienia. Zajczyk - jakkolwiek szczerze kochający swego syna — popełnia gwałt na jego dziecięcej psychice i zmusza go do oglądania sceny egzekucji. Chcą przystosować potomka do funkcjonowania $\mathrm{W}$ rzeczywistości imperium, musi przyczynić się do jego demoralizacji.

Taka też jest diagnoza Kociubynskiego: kariera w imperialnej rzeczywistości wiąże się nieodzownie z procesem moralnego upadku jednostki. Rusyfikację na przykładzie Prezentu... można zatem traktować nie jako stopniowe rugowanie z użycia języka tubylczego, lecz przede wszystkim jako proces przyswajania pewnych wzorców zachowań.

Kontekst autobiograficzny jest w tym przypadku szczególnie ciekawy. Mychajło Kociubynski był wychowany w rosyjskojęzycznej rodzinie, której ojciec miał identyczny przebieg kariery, co literacki bohater Karpo Petrowycz. Wybór języka ukraińskiego oraz bycie ukraińskim pisarzem oznaczało dla Kociubynskiego swoiste renegactwo, funkcjonowanie poza rzeczywistością państwową. Legalnym pisarzem mógł być jedynie wówczas, gdyby zgodził się publikować swoje utwory w języku rosyjskim. Wybierając inną drogę, musiał pogodzić się z tym, że na utrzymanie rodziny będzie zarabiał jako... urzędnik państwowy. Swych kolejnych stanowisk już to członka komisji ds. filoksery, już to kierownika biura statystycznego w Czernihowie - Kociubynski szczerze nienawidził. Imperium Rosyjskie w najprostszy sposób zmusiło jednak pisarza, by grał według jego zasad. Jeżdżąc na kolejne ekspedycje był takim samym, jak inni urzędnicy wykonawcą dyrektyw centrum, które - co pokazał pisarz w opowiadaniu Dla dobra ogótu - były realizowane kosztem jednostki. Dopiero na dwa lata przed śmiercią, w 1911 roku, dzięki dożywotniemu stypendium lwowskiego Towarzystwa Miłośników Ukraińskiej Nauki, Literatury i Sztuki Mychajło Kociubynski mógł zwolnić się ze służby Imperium.

Myśl o demoralizującym wpływie władzy rozwinął dwa lata później po Kociubynskim Wołodymyr Wynnyczenko. W opowiadaniu Cierń [Tерень] nie pozostawił złudzeń, co do tego, że sprawowanie władzy wiedzie ku degradacji moralnej. Co ciekawe, Wynnyczenko analizuje w tym przypadku władzę jako samą w sobie, bez imperialnego czy kolonialnego kontekstu.

Tytułowy bohater Cierń jest wiejskim bardem, który w swoich autorskich pieśniach demaskuje przejawy społecznej niesprawiedliwości: „(...) пісня парубка була справді сумна. В ній просто й з тою нелукавою класичною красою, $з$ якою гуде ліс, скиглить чайка, плаче пугач на могилі, оповідалась історія дівчини, що попада на завод. Завод, мабуть, був цукроварний; там, як співалося в пісні, „солодкий цукор мішають 3 гіркими сльозами”, „за копійку душі порять, за дві винимають"

${ }^{11}$ Там само, с. 591. 
Cierń jest solą w oku miejscowych władz. Ani przystaw, ani starosta, ani w końcu batiuszka nie są w stanie sprawić, by zamilkł głos sprawiedliwości: „Вже чого 3 ним не робили: роботи йому не давали, з лавки нічого не продавали, усовіщали, арештовували, забирали в його папір, книжки, тюрмою грозились. Тереньові те все тільки привід до нової пісні. Старшина просто радив на підставі циркуляру „про боротьбу з хуліганством на селах” вислати по приговору чортового парубка аж на Сибір, та й край. Але писар і інші не рішались: більшість на сході була б проти. Тут уже голота вступилась би за свого, міг би вийти непорядок і пониження власті"12.

Ostatecznie jednak znaleziono wyjście z impasu. Na tajnej naradzie u popa postanowiono o zaproponowaniu Tereniowi dobrze płatnej posady młodszego skryby. Początkowo zmiana pozycji społecznej i materialnej nie wpłynęła na zmianę postępowania Ciernia. Jednak z czasem z wiejskiego barda przeistacza się w rozpitego i skorumpowanego urzędnika, który znęca się nad nieszczęsnymi chłopami, o ciężkim losie których jeszcze niedawno układał żarliwe pieśni.

Co symptomatyczne, Wynnyczenko nie wprowadza w powyższym tekście kontekstu narodowościowego. Swego awansu społecznego Cierń nie przypłaca tożsamościowym przesunięciem, tak jak czynił to Guzik z opowiadania $W$ cieniu maszyny [Біля машини], który za wszelką cenę pragnie odgrodzić się od chłopówUkraińców i stać się panem-Polakiem. Obiektem analizy w tym przypadku jest władza jako taka i jej wpływ na kondycję człowieka. Wynnyczenko jest tutaj zdecydowanym pesymistą i skłania się ku poglądom anarchistycznym. To zresztą koreluje z opiniami o Wynnyczence jego współczesnych. Swego czasu Jewhen Czykałenko napisał do autora Зіни: W swej szczerości jest Pan bardzo utalentowanym człowiekiem, ale również, proszę wybaczyć - dzika, anarchistyczna, rujnującą siłą ${ }^{13}$. I nawet wiedząc o członkostwie Wynnyczenki w socjalistycznej partii, jego mecenas utrzymywał, że charakter pisarza jest $\mathrm{w}$ istocie anarchistyczny.

Problem władzy jest zatem miejscem, w którym obaj pisarze zaczynaja mówić wspólnym językiem. Jest to spowodowane tym, że właśnie władza (czy też odwrotnie — jej deficyt) jest istotą spotkania kolonialnego. W świadomości Ukraińców władza jest zawsze przestrzenią zdominowaną przez Innego, do której oni sami nie mają dostępu, lub też dostęp ten warunkowany jest poważnymi kompromisami w obrębie własnej tożsamości. Poprzez fakt, że dysponentem władzy jest wyłącznie kolonizujący Inny, również władza jako taka zaczyna kumulować negatywne asocjacje. Prezent na urodziny Kociubynskiego oraz Cierń Wynnyczenki to przykłady sceptycznych odpowiedzi na możliwość zachowania cnót moralnych przy jednoczesnym zwiększaniu swojej władzy i wpływów. Omówione powyżej teksty mogą stanowić przykład literackich egzemplifikacji do dyskusji wokół jednego z najważniejszych ukraińskich problemów społeczno-politycznych, który historyk Wiaczesław Łypynski trafnie określił jako „choroba bezpaństwowości”.

12 Там само, с. 599.

13 Цит. за: В. Панченко, Творчість Володимира Винниченка 1902-1920 рр. у генетичних i типологічних зв'язках з європейскими літературами, [в:] Електронний ресурс: http://library. kr.ua/books/panchenko/ (13.01.2014). 